\title{
On-farm welfare assessment in meat goat does raised in semi-intensive and extensive systems in semiarid regions of Ceará, Northeast, Brazil
}

\author{
Luana Oliveira Leite ${ }^{*^{*}}$ Fabiana de Orte Stamm² $^{2}$ Marcelo Adriano Corrêa Maceno ${ }^{3}$ (D) \\ Jomar Antonio Camarinha Filho ${ }^{3}$ (D) Rita de Cassia Maria Garcia ${ }^{4}$ (D)
}

\footnotetext{
${ }^{1}$ Programa de Pós-graduação em Ciências Veterinárias, Universidade Estadual do Ceará (UECE), 60714.903, Fortaleza, CE, Brasil. E-mail: luanaoliv.vet@gmail.com. *Corresponding author.

${ }^{2}$ Programa de Pós-graduação em Zootecnia, Universidade Federal do Paraná (UFPR), Curitiba, PR, Brasil.

${ }^{3}$ Departamento de Estatística, Setor de Ciências Exatas, Universidade Federal do Paraná (UFPR), Curitiba, PR, Brasil.

${ }^{4}$ Departamento de Medicina Veterinária, Setor de Ciências Agrárias, Universidade Federal do Paraná (UFPR), Curitiba, PR, Brasil.
}

\begin{abstract}
The aim of this study was to apply a protocol based on the Animal Welfare Indicators (AWIN) protocols for small ruminants in Brazilian Northeast farms to evaluate the welfare of meat goat, comparing animals kept on semi-intensive (S) and extensive (E) farms. Fifteen farms located in the Metropolitan Region of Quixadá and Quixeramobim, Ceará, Brazilian Northeast, were recruited. Assessments were performed at group and individual level. Significant differences between $S$ and E farms was set at $P<0.05$ to all tests. At group level, there was a significant difference between groups, with more goats from $E$ farms affected by heat stress and more animals from $S$ farms presenting oblivion. Resource-based indicators, type of drinkers and access to shelter, differed significantly between $S$ and $E$ systems, with goats on $S$ farms allocated in places with access to water more frequently during night period and protected from wind. Type of facility was more complex for animals on $S$ farms $(n=2)$ than on all $E$ farms due to internal divisions, with $S$ farms presenting feeders, drinking fountains, salt shakers, and slatted or cemented floor. At individual level, abscess and ocular discharge were more frequently observed on $S$ farms and ears lesions were more frequent on E farms, probably due to distinct management of goats. Similarities between results showed that farmers in both production systems faced problems related to heat stress, lack of forage and health issues.

Key words: animal welfare, AWIN protocol, production system, human-animal relationship, physiological indicators.
\end{abstract}

Avaliação do bem-estar em fazendas de cabras de corte criadas em sistemas semi-intensivo e extensivo em regiões semiáridas do Ceará, Nordeste, Brasil

RESUMO: O objetivo deste estudo foi aplicar um protocolo baseado nos protocolos Animal Welfare Indicators (AWIN) de pequenos ruminantes em fazendas do nordeste brasileiro para avaliar o bem-estar de cabras de corte, comparando animais mantidos em fazendas semi-intensivas (S) e extensivas (E). Quinze fazendas localizadas na Região Metropolitana de Quixadá e Quixeramobim, no Ceará, Nordeste do Brasil, foram recrutadas. As avaliações foram realizadas no nivel de grupo e individual. A diferença significativa entre as fazendas $S$ e $E$ foi estabelecida em $P<0,05$ para todos os testes. No nivel de grupo, houve diferença significativa, com mais cabras do grupo E afetadas por estresse térmico e do grupo $S$ apresentando apatia. Indicadores baseados em recursos, tipo de bebedores e acesso a abrigos diferiram significativamente entre os sistemas $S$ e E, com cabras em fazendas $S$ alocadas em locais com acesso à água durante o periodo noturno mais frequentemente e protegidas do vento. O tipo de instalação era mais complexo para os animais nas fazendas $S(n=2)$ do que nas fazendas $E$, devido as divisões internas, com a presença de comedouros, bebedouros, saleiros, piso ripado ou cimentado em fazendas $S$. A nivel individual, abscesso e secreção ocular foram observados mais frequentemente nas fazendas $S$, e lesões nas orelhas, nas fazendas $E$, provavelmente devido ao manejo distinto das cabras. Semelhanças entre os resultados mostraram que os fazendeiros de ambos os sistemas de produção enfrentam problemas relacionados ao estresse térmico, falta de forragem e problemas de saúde.

Palavras-chave: bem-estar animal, protocolo AWIN, sistema de produção, relacionamento humano-animal, indicadores fisiológicos.

\section{INTRODUCTION}

Raising goats in Brazilian Northeast is an important social-economic activity, especially for middle and low income people, being an essential source of milk, protein and goatskin (SILVA \&
ARAÚJO, 2000). More than $90 \%$ of goats live in this region, with Ceará being the fourth largest state that raises goats in Brazil (IBGE, 2016). Although Northeast has the largest number of goats in Brazil, rearing is mainly aimed to the subsistence of farmers with several limitations to the growth of 
this activity. Productivity of herds is quite restricted due to technological and handling limitations as difficult access to forage during dry season; lower genetic quality of herds, with precarious reproductive management practice, as lack of male control; sanitary conditions, as mortality of young animals, that occurs as a result of infectious and parasitic diseases, leading to high mortality rates (SEBRAE, 2009). In addition, almost all of Ceará's territory is inserted in semiarid region (IPECE, 2005), characterized by hot and dry climate, irregular rains concentrated in few months, with water scarcity, especially during dry periods, and Caatinga as the main vegetation type (ARAÚJO, 2011). This context possibly hinders the development of goat rearing in Ceará, regardless of type of system in which these animals are raised.

In extensive systems, the main system in Northeast (McMANUS et al., 2014), goats are kept in rudimentary facilities and they are fed on natural pastures. Conversely in semi-intensive systems, animals have supplemental feed and better health management practices (CODEVASF, 2011).

Welfare assessment of farm animals, sentient beings, has been increasingly worldwide (BLOKHUIS et al., 2010). Species-specific protocols have been developed aiming to identify the challenges faced by farm animals and searching for solutions to promote a better quality of life for them (WELFARE QUALITY ${ }^{\circledR}, 2009$; AWIN PROJECT, 2015).

AWIN Goat protocol was designed to assess the welfare of adult lactating dairy goats raised in intensive and semi-intensive systems, with a primary focus on animal-based indicators (AWIN GOAT, 2015). Although there was no specific protocol for meat goat does, the authors suggested indicators that could be used to evaluate the welfare of these animals in Brazilian Northeast (AWIN GOAT, 2015; AWIN SHEEP, 2015; LEITE et al., 2017). Therefore, the aim of the present study was to apply a protocol to evaluate the welfare of meat goat does in Brazilian Northeast farms, comparing animals kept on semi-intensive and extensive farms, quantifying the welfare problems in both groups and describing some considerations related to the protocol.

\section{MATERIALS AND METHODS}

Farms were recruited via local goats' meat farmers associations. Fifteen farms located in the Metropolitan Region of Quixadá and Quixeramobim, Ceará, Brazilian Northeast were visited in July 2016. This region have Caatinga biome which occurs in the semiarid region of Brazilian Northeast, mainly composed of an irregular climate, with strong insolation, high evaporation rates and low rainfall, and a predominance of deciduous plant species (LOIOLA et al., 2012).

Farms were organized in two groups, extensive (E) or semi-intensive (S), according to the definition by CODEVASF (2011). In extensive systems, goats are kept in rudimentary facilities, defined as installations with bare soil, absence of internal divisions, containing or not troughs for the animals (ALENCAR et al., 2010), animals are fed only on natural pastures and the use of technology for the production system is low (CODEVASF, 2011). Semi-intensive systems are characterized by a higher use of technology than extensive systems: animals have supplemental feed and frequent health management (CODEVASF, 2011). Pinheiro et al. (2000) observed that farms in extensive $(n=99 ; 78 \%)$ systems are the majority compared to other systems in Ceará, which was also observed in this study, being easier to find $\mathrm{E}$ farms in contrast to $\mathrm{S}$ farms (Table 1).

On five farms (farms 01 to 05), animals were maintained in semi-intensive (S) systems. S farms had higher frequency of hooves trimming than $\mathrm{E}$ farms, and presented infirmary and quarantine facilities (Table 1). Besides, S systems commonly had an installation with raised and slatted floors, with internal divisions, and the presence of feeders, drinking fountains and salt shakers. On ten farms (farms 06 to 15), animals were kept in extensive (E) systems, with animals being released early during day time and housed before night, being fed only on natural pastures of Caatinga. Number of farms in each group was different because during the study it was not possible to contact more $\mathrm{S}$ farms due to the lack of this type of farm in the evaluated region. Assessments in $\mathrm{S}$ and $\mathrm{E}$ farms occurred during morning (07:00 a. $\mathrm{m}-12: 00$ a.m.) or afternoon (01:00 p.m. - 04:00 p.m.) periods, on both groups (three $\mathrm{S}$ farms during morning and two during afternoon and six $\mathrm{E}$ farms during morning and four during afternoon).

Assessed meat goat does have at least seven months and were raised for breeding or meat purposes. On $\mathrm{S}$ farms, pure breed meat goats occurred on most properties $(n=3 ; 60 \%)$, presenting Boer, Savana, and Kalahari goats. On E farms, mixed breeds composed of two or more different breeds as Anglo-Nubian, Saanen, Alpine goat, Boer, and Toggenburg were presented $(\mathrm{n}=10 ; 100 \%)$. On all assessed farms, the animals were used by farmers for their own consumption, goatskin trade, competition in agricultural events, and sale of living goats in local fairs or abattoirs.

A protocol for assessing welfare of meat goat does was designed considering aspects of the 
Table 1 - Description of the number of goats evaluated on S and E farms, at first and second levels of welfare assessment, established by AWIN sheep (AWIN SHEEP, 2015) and goat (AWIN GOAT, 2015) protocols.

\begin{tabular}{|c|c|c|c|c|c|}
\hline Farm & $\begin{array}{l}\text { Production system } \\
\text { (Semi intensive }-\mathrm{S} \text {; } \\
\text { Extensive }-\mathrm{E})\end{array}$ & $\begin{array}{c}\text { Number of goat } \\
\text { does }\end{array}$ & $\begin{array}{l}\text { First welfare level } \\
\text { (group 1) }\end{array}$ & $\begin{array}{l}\text { First welfare level } \\
\text { (group 2) }\end{array}$ & $\begin{array}{l}\text { Second welfare Leve } \\
\text { (individual) }\end{array}$ \\
\hline Farm 01 & $\mathrm{~S}$ & 107 & 31 & 0 & 47 \\
\hline Farm 02 & $\mathrm{~S}$ & 346 & 19 & 19 & 56 \\
\hline Farm 03 & $\mathrm{~S}$ & 14 & 14 & 0 & 14 \\
\hline Farm 04 & $\mathrm{~S}$ & 18 & 18 & & 18 \\
\hline Farm 05 & $\mathrm{~S}$ & 18 & 18 & 0 & 16 \\
\hline Farm 06 & $\mathrm{E}$ & 18 & 18 & 0 & 18 \\
\hline Farm 07 & $\mathrm{E}$ & 30 & 30 & 0 & 22 \\
\hline Farm 08 & $\mathrm{E}$ & 7 & 7 & 0 & 7 \\
\hline Farm 09 & $\mathrm{E}$ & 44 & 44 & 0 & 26 \\
\hline Farm 10 & $\mathrm{E}$ & 13 & 13 & 0 & 13 \\
\hline Farm 11 & $\mathrm{E}$ & 27 & 27 & 0 & 19 \\
\hline Farm 12 & $\mathrm{E}$ & 22 & 22 & 0 & 16 \\
\hline Farm 13 & $\mathrm{E}$ & 50 & 50 & 0 & 29 \\
\hline Farm 14 & $\mathrm{E}$ & 17 & 17 & 0 & 17 \\
\hline Farm 15 & $\mathrm{E}$ & 36 & 36 & 0 & 26 \\
\hline
\end{tabular}

reality of these animals in the Brazilian northeastern semiarid. This protocol was elaborated based on AWIN protocols structure: first (Table 2) and second (Table 3) welfare levels of assessment (AWIN PROJECT, 2015). Animal and resource-based indicators applied to dairy goats (AWIN GOAT, 2015) and ewes (AWIN SHEEP, 2015) were selected (for more details see <https://air.unimi.it/retrieve/ handle/2434/269102/384790/AWINProtocolGoats. pdf $>$ for goats, or <https://air.unimi.it/ bitstream/2434/269114/2/AWINProtocolSheep.pdf> for sheep). Some parameters based on the literature on goat health (CAROPRESE et al., 2009) and type and cleanliness of facilities for small ruminants in Brazilian Northeast were also added (SEBRAE, 2009; ALENCAR et al., 2010; CODEVASF, 2011; LEITE et al., 2017).

The person who assessed the goats is a veterinarian who had one year of experience with goat management and she was also trained on diagnosis of animal welfare. The evaluator was trained using the AWIN application for goats available on the Play Store (Android) for 20 hours and had the assistance of one of the co-authors (FOS) who applied the AWIN protocol on sheep during her master's study. A practical training session at the Experimental Farm of Federal University of Paraná was taken, which had the duration of three hours.

The first level of welfare assessment includes behavioural and health observations of the animals, human-animal relationship and resources data. The second level of assessment includes the individual evaluation of the goats. Table 1 shows the number of animals evaluated at first and second welfare levels of assessments on each farm. At first welfare level, two groups of animals, kept in fenced fields or in pens (no farm raised free range meat goats), were evaluated on each farm. In case there was only one group in the farm, only this was assessed. Groups were randomly selected and goats kept in infirmary and quarantine were not considered. No physical contact was performed with animals at this level. Evaluations started outside the pens/fields and then inside. Superficial temperature $(\mathrm{T})\left({ }^{\circ} \mathrm{C}\right)$ and relative humidity of air $(\mathrm{RH})(\%)$ were calculated with Digital Thermo Hygrometer ITHT2210, and local time were recorded at the beginning of each assessment.

Table 2 describes parameters used to assess goat's welfare. Lameness, access to shade and shelter, water availability and facility indicators were subdivided into variables to suit the analyses. Familiar Human Approach Test (FHAT) was applied to measure flight distance of meat goat does from stockperson approach. Vulvar discharge was selected based on pathologies related to reproductive organs as caprine herpes virus or pseudo pregnancy (PUGH, 2002). Facility parameter was proposed by authors to identify the type of installation and floor used more frequently by farmers aiming to verify cleanliness of facilities and frequency of cleanness. The last is 
Table 2 - Indicatorswith their respective categories (Animal Health-H; Human-Animal Relationship - HAR; Resources - R) used to assess meat goat does at first welfare level in Ceará, Brazil.

\begin{tabular}{|c|c|}
\hline Indicator & Description \\
\hline${ }^{\mathrm{a} O b l i v i o n}{ }^{\mathrm{H}}$ & The number of goats physically or mentally isolated from the group is recorded. \\
\hline${ }^{\mathrm{a}}$ Thermal stress ${ }^{\mathrm{H}}$ & $\begin{array}{c}\text { Number of goats showing heat (high accelerate respiration rate) or cold (shivering or presence of } \\
\text { bristly hair) stress signs is counted. }\end{array}$ \\
\hline${ }^{\mathrm{a}}$ Faecal soiling ${ }^{\mathrm{H}}$ & The presence of soft and liquid manure below the tail head is visually assessed as a sign of diarrhea. \\
\hline${ }^{\mathrm{a}}$ Hair coat condition ${ }^{\mathrm{H}}$ & $\begin{array}{l}\text { The number of goats presenting poor hair coat (defined as matted, rough, scurfy, uneven, shaggy } \\
\text { hair coat frequently longer than normal) is recorded. }\end{array}$ \\
\hline $\begin{array}{l}\text { bameness score } \\
\text { Score } 0 \\
\text { Score } 1 \\
\text { Score } 2 \\
\text { Score } 3\end{array}$ & $\begin{array}{l}\text { Goats are moved into the fenced fields and the number of lame animals is recorded. } \\
\text { Not lame. Goat's weight is borne on all four feet. } \\
\text { Head nodding is perceived or the limb is rapidly lifted when touches the ground. } \\
\text { Obvious head nodding is perceived; foot may be held-up whilst standing; goats may be grazing on } \\
\text { knees. } \\
\text { Goat is lying down and do not move. Animal is reluctant to stand or move. }\end{array}$ \\
\hline $\begin{array}{l}{ }^{\mathrm{b}} \text { Familiar Human Approach } \\
\text { Test }\left(\text { FHAT) }{ }^{\text {HAR }}\right.\end{array}$ & $\begin{array}{l}\text { The closest distance }(\mathrm{m}) \text { of approach the group, before a flight response is evoke, is recorded. If an } \\
\text { animal stands motionless, this is recorded as } 0 \mathrm{~m} \text {. Animals that approach voluntary and/or interact } \\
\text { (sniffing or touching) are also recorded. }\end{array}$ \\
\hline $\begin{array}{l}{ }^{\mathrm{d}} \text { Stocking density } \\
\text { Good } \\
\text { Adequate } \\
\text { Poor }\end{array}$ & $\begin{array}{l}\text { The size of pen/housing dimensions }\left(\mathrm{m}^{2}\right) \text { is recorded and divided for the number of goats inside. } \\
\text { Goats have, at least, } 2 \mathrm{~m}^{2} \text { each. } \\
\text { Goats have at least } 1.51 \mathrm{~m}^{2} \text { but less than } 2 \mathrm{~m}^{2} . \\
\text { Goats have } 1.5 \mathrm{~m}^{2} \text { or less. }\end{array}$ \\
\hline${ }^{\mathrm{b}}$ Access to shade and shelter ${ }^{\mathrm{R}}$ & The presence of shade and shelter is recorded. \\
\hline $\begin{array}{l}{ }^{\mathrm{b}} \text { Water availability }{ }^{\mathrm{R}} \\
\text { Presence and type } \\
\text { Functioning } \\
\text { Cleanliness }\end{array}$ & $\begin{array}{l}\text { The number and type of water point (bucket, automatic drinker and natural water source) is } \\
\text { recorded. } \\
\text { Presence of water and type of drinkers. } \\
\text { Check if the water point is functioning. } \\
\text { Dirty (water and water points are dirty; natural water source are stagnant or polluted); Partially } \\
\text { dirty (water points are dirty but the water is clean); Clean (water and water points are clean; natural } \\
\text { water source are clean and unpolluted). }\end{array}$ \\
\hline $\begin{array}{l}{ }^{\mathrm{c}} \text { Facility }{ }^{\mathrm{R}} \\
\text { Type of facility } \\
\text { Type of floor } \\
\text { Cleanliness }\end{array}$ & $\begin{array}{l}\text { Type of facility and floor, besides the cleanliness of the installations, were recorded. } \\
\text { Classification of facility: goat houses rustic facilities. } \\
\text { Classification of floor: bare soil, cement, cement with bare soil, suspended slatted floor or } \\
\text { suspended slatted floor with a sun area with bare soil. } \\
\text { Dirty (The floor was covered with faeces in more than } 75 \% \text { of the area); Partially dirty (the floor } \\
\text { was covered with faeces in an area between } 25 \text { and } 75 \% \text { of the floor); Clean (The floor was covered } \\
\text { with faeces in less than } 25 \% \text { of the area). }\end{array}$ \\
\hline
\end{tabular}

\footnotetext{
${ }^{a}$ Indicators are from AWIN GOAT (2015)

${ }^{\mathrm{b}}$ Indicators are from AWIN SHEEP (2015)

${ }^{\mathrm{c}}$ Indicator proposed by authors and based on LEITE et al. (2017)

${ }^{\mathrm{d}}$ Indicator modified from AWIN SHEEP (2015) and MIRANDA-DE LA LAMA \& MATTIELLO (2010)

Table was adapted from Battini et al. (2015)
}

an indicator based on management. Indicators were scored according to AWIN GOAT (2015) and AWIN SHEEP (2015) and stocking density was classified in categories. Stocking density was divided in poor $\left(\leq 1.5 \mathrm{~m}^{2}\right)$, adequate (between 1.51 and $\left.1.99 \mathrm{~m}^{2}\right)$ and good $\left(\geq 2 \mathrm{~m}^{2}\right)$. This indicator was proposed based on AWIN SHEEP (2015) and MIRANDA-DE LA LAMA \& MATIELLO (2010).

At second welfare level, a number of animals were selected, according to the total number of animals on each farm (AWIN GOAT, 2015), and individual assessments were carried out using animalbased indicators. Eight parameters were selected to be applied on meat goat does (Table 3). Lesions (L) were divided in six variables: $\mathrm{L}$ in ears, $\mathrm{L}$ in eyes, $\mathrm{L}$ in face/muzzle, L on neck, L on body, L on udder and teats. These variables were also classified regarding presence/absence of myiasis: absent (0); presence of minor lesion with myiasis; presence of minor lesion without myiasis; presence of major lesion with 
Table 3 - Indicators used to assess meat goat does at second welfare level in Ceará, Brazil.

\begin{tabular}{|c|c|}
\hline Indicator & Description \\
\hline Body Condition Score (BCS) & BCS is asses using a five-level (1-5) scoring method (VILAQUIRAN et al., 2004). \\
\hline${ }^{\mathrm{a}}$ Faecal soiling & $\begin{array}{l}\text { The presence of soft and liquid manure below the tail head is visually assessed as a sign of } \\
\text { diarrhea.The assessment is done in the same way as at the first level of welfare. }\end{array}$ \\
\hline${ }^{\mathrm{a}} \mathrm{Abscess}$ & The presence of external abscesses in front area is recorded. \\
\hline${ }^{a}$ Nasal discharge & The presence of any mucous or purulent discharge from the nose is visually assessed. \\
\hline${ }^{\mathrm{a} O c u l a r}$ discharge & The presence of clearly visible flow from one or two eyes is visually assessed. \\
\hline${ }^{\mathrm{b}}$ Vulvar discharge & $\begin{array}{c}\text { The presence of any mucous, purulent or sanguineous discharge from the vulva is visually } \\
\text { assessed. }\end{array}$ \\
\hline${ }^{\mathrm{c}}$ Respiration quality & $\begin{array}{l}\text { The presence of obvious effort on inspiration, persistent coughing and audible breath sounds } \\
\text { is recorded. }\end{array}$ \\
\hline $\begin{array}{l}{ }^{\mathrm{d}} \text { Lesions on head, body and udder teats } \\
\text { No lesions } \\
\text { Minor } \\
\text { Major }\end{array}$ & $\begin{array}{l}\text { The presence of lesions is recorded, with or without myiasis (presence of maggots on } \\
\text { animal). } \\
\text { No evidence of lesions in all these parts. } \\
\text { Lesions type (scratches, healed, open wounds, ear notches) that are greater than } 2 \mathrm{~cm} \text { and less } \\
\text { than } 10 \mathrm{~cm} \text {, without blood. } \\
\text { Wounds greater than } 10 \mathrm{~cm} \text {, opened, and that reach or not the muscle layer.Ear cuts, already } \\
\text { healed, greater than } 10 \mathrm{~cm} .\end{array}$ \\
\hline
\end{tabular}

${ }^{\mathrm{a}}$ Indicators from AWIN GOAT (2015)

${ }^{\mathrm{b}}$ Indicator from PUGH (2002)

${ }^{c}$ Indicators are from AWIN SHEEP (2015)

${ }^{\mathrm{d}}$ Indicator modified from AWIN SHEEP (2015)

myiasis; presence of major lesion without myiasis. The number of meat goat does individually assessed was determined by AWIN Goat protocol (AWIN GOAT, 2015).

Data were analyzed using IBM SPSS, v. 19. At first and second welfare level of assessments, indicators were processed comparing $\mathrm{E}$ and $\mathrm{S}$ farms. Data normality was evaluated with Shapiro-Wilk test. Only data related to humidity and temperature had a normal distribution. To compare the mean values of temperature and relative humidity between the two groups of farms (S and E), Student $t$ test was applied. In data without normal distribution, nonparametric statistical tests were applied for intergroup comparison. For health animal-based indicators at group level, the prevalence of each indicator was calculated on total number of goats and at farm level, and the significant difference was determined by Chi-square test. Regarding the humananimal relationship indicator, Familiar Human Approach Test (FHAT), significant difference was measured by Mann-Whitney testin which the flight distance in meters (dependent variable) was evaluated according to $\mathrm{S}$ and $\mathrm{E}$ farms (independent variable). For resource animal-based indicators, qualitative indicators with ordinal variables as cleanliness of drinkers and facilities were analyzed with MannWhitney test. Others resource-based parameters were determined by Chi-square test.

For animal-based indicators at individual level, the prevalence of each indicator was calculated on total number of goats and at farm level. Significant difference related to Body Condition Score (BCS), a qualitative ordinal variable, was calculated with Mann-Whitney test. For animal-based parameters, the prevalence of each indicator was calculated on total number of goats and at farm level, and the significant difference was determined by Chi-square test. Fisher's exact test was used, instead of Chisquare test, every time that the number of cells on 2X2 contingency table was below five. Significance was set at $\mathrm{P}<0.05$ to all tests.

\section{RESULTS AND DISCUSSION}

At the first welfare level, 16 groups were evaluated (Table 1). 383 meat goat does were evaluated at pen/fenced field level, with 119 on S farms and 264 on $\mathrm{E}$ farms. S farms had a higher mean number of animals (mean \pm SD: $101 \pm 143$ ) than $E$ farms (mean \pm SD: $26 \pm 14$ ). Mean values of temperature (T) on farms were $31.96{ }^{\circ} \mathrm{C}$ (min-max: 29.0 - $34.7{ }^{\circ} \mathrm{C}$ ) 
and $34.25{ }^{\circ} \mathrm{C}$ (min-max: $31.40-36.72{ }^{\circ} \mathrm{C}$ ) during morning $(07: 00 \mathrm{~h}-12: 00 \mathrm{~h})$ and afternoon $(13: 00 \mathrm{~h}$ - 16:00h), respectively. Mean values of relative humidity of air (RH) on farms were $53.41 \%$ (min$\max : 43.76$ - 68.17\%) and 40.96\% (min-max: 34.22 $51.31 \%$ ), during morning and afternoon, respectively. There was significant difference between assessments started in morning compared to afternoon in relation to relative humidity $(\mathrm{P}=0.008)$ but not to temperature $(\mathrm{P}=0.05)$. Therefore, for the indicator heat stress, the time of the assessment on farms may have had some influence over the result. Along with temperature, another factor that impacts animal welfare and productivity is RH (SILANIKOVE, 2000). Although, low RH rates promote more efficiently evaporation mechanisms, they can also cause irritation on mucous membrane and respiratory problems (FAO \& INPhO, 1998; SILANIKOVE, 2000). In our study in the afternoon, there were evaluations on $\mathrm{E}$ farms with RH below 40\% (Farms 08, 11, 12 and 15), and the adequate range are between 40 and $80 \%$ (FAO \& INPhO, 1998).

Health-based indicators on goats in $\mathrm{S}$ and $\mathrm{E}$ farms are showed on Table 4. Oblivion goats were observed more frequently on $\mathrm{S}$ than on $\mathrm{E}$ farms. Goats are gregarious animals that only isolate themselves in parturition (LICKLITER, 1985) or sickness (BATTINI et al., 2014). Due to the fact that animals kept in semi-intensive systems had greater contact with humans, e.g. during feeding with concentrate, the authors expected a lower occurrence of this indicator on $\mathrm{S}$ farms. Therefore, although few animals presented this indicator per farm, there is a need for greater inspection of all animals to identify isolated ones and search for a diagnosis that assists in maintaining individual and herd health.

Thermal stress was only observed on E farms (Table 4). On three $\mathrm{E}$ farms, ambient temperature was above $34{ }^{\circ} \mathrm{C}$, a critical temperature according to Battini et al (2016), causing heat stress on goats. In our study, meat goat does, in general, spent all day at unfenced pasture in Ceará, so it is important to provide adequate water sources in specific points outside facilities (NEW ZEALAND GOVERNMENT, 2018). However, it is important to note that thermal stress assessment in our study occurred approximately 15-20 minutes after goats were set up in the facility in mostly $\mathrm{E}$ farms, after being at pasture (including the three farms with panting animals, Table 4). Since goats are adapted to hot climates (SILANIKOVE, 2000), it is possible that thermal stress behavior observed on goats where not caused by a high temperature, but because some individuals may have become physically fatigued during the journey and did not have enough time to recover. It is necessary to investigate whether there is a greater need for a rest time after arriving from the pasture for a thermal stress assessment.

High prevalence of goats with poor hair condition in $\mathrm{S}$ and $\mathrm{E}$ farms (Table 4) could be due to pathologies or diseases on animals (BERG et al., 2009). On the other hand low incidence of lameness in goats in this study could be due to inexistence of several problems that cause this

Table 4 - Prevalence of animal health-based indicators on all assessed goats in the six groups ( $\mathrm{n}=119)$ from $\mathrm{S}$ farms and on ten groups $(n=264)$ from $E$ farms, during the first level of welfare assessment, in Ceará, Brazil.

\begin{tabular}{|c|c|c|c|c|c|}
\hline \multirow{2}{*}{$\begin{array}{l}\text { Animal } \\
\text { indicators }\end{array}$} & \multicolumn{2}{|c|}{ Number (\%) } & \multicolumn{2}{|c|}{ Number (\%) } & \multirow[t]{2}{*}{ P-value } \\
\hline & Goats & $\mathrm{S}$ groups & Goats & E groups & \\
\hline Oblivion & $5(4.20)$ & $2(33.33)$ & $1(0.37)$ & $1(10.0)$ & $0.012^{*}$ \\
\hline Thermal stress & $0(0.0)$ & $0(0.0)$ & $11(4.16)$ & $3(30.0)$ & $0.021^{*}$ \\
\hline Faecal soiling & $0(0.0)$ & $0(0.0)$ & $0(0.0)$ & $0(0.0)$ & - \\
\hline Hair coat condition & $10(8.40)$ & $3(50.0)$ & $32(12.12)$ & $8(80.0)$ & 0.245 \\
\hline Minor lameness & $2(1.68)$ & $2(33.33)$ & $1(0.37)$ & $1(10.0)$ & 0.228 \\
\hline Lame & $0(0.0)$ & $0(0.0)$ & $3(1.13)$ & $3(30.0)$ & 0.555 \\
\hline Severely lameness & $0(0.0)$ & $0(0.0)$ & $0(0.0)$ & $0(0.0)$ & - \\
\hline
\end{tabular}

${ }^{*}$ Significant difference $(\mathrm{P}<0.05)$. 
condition as foot pathologies, e.g. infectious foot rot, and infectious and non-infectious diseases (PUGH, 2002). Overgrown hooves are an important predisposing factor to lameness in goats (EZE, 2002; CHRISTODOULOPOULOS, 2009). However, most goats in this study have contact with bare soil due to the breeding system (extensive in E farms) or the pen/fenced field where they live. In the semiarid region of Brazilian Northeast, the main types of soils reported are chromic luvisols, being little depth and containing stones on their surface (ALMEIDA et al., 2020) which can promote natural abrasion on the hooves, thus preventing lameness on goats.

Regarding to Human-Animal Relationship (HAR) indicator, FHAT, values of $\mathrm{E}$ farms 13 and 14 were removed because it was not possible to evaluate on their current facility. This occurred because goats were already on pasture when the evaluator arrived, and for management reasons on farms, it was not possible to relocate the animals in their installation. Flight distance measured by FHAT showed mean values of $133.1 \mathrm{~cm}$ (min-max: 0 -
$345 \mathrm{~cm})$ and $124.1 \mathrm{~cm}(\min -\max : 57-239 \mathrm{~cm})$ on $\mathrm{S}$ and $\mathrm{E}$ farms, respectively. There was no statistical difference $(\mathrm{P}=0.473)$ between $\mathrm{S}$ and $\mathrm{E}$ farms, and flight distance was zero in only one S group (farm 04) and none goat sought voluntary human contact. Flight behavior occurred in farmed species in situations of fear or anxiety probably due to negative previous experiences as restraint practices for deworming or vaccination (WAIBLINGER et al., 2006). Positive interactions are associated with high confidence levels in human beings and low fear reactions, e. $\mathrm{g}$. regular gentle handling may provide a more friendly environment in aversive situations (WAIBLINGER et al., 2006). This interaction is recommended in the management of meat goat does to improve HAR and their welfare.

Results related to some resourcebased indicators are showed in Table 5. Due to a methodological error, stocking density was not assessed on one $\mathrm{S}$ farms (Farm 01) and two E farms (14 and 15). All farms evaluated were classified as good considering stocking density $\left(\geq 2 \mathrm{~m}^{2}\right)$. An

Table 5 - Characterization of three variables of resource-based indicators on $\mathrm{S}(\mathrm{n}=5)$ and $\mathrm{E}$ farms $(\mathrm{n}=10)$ in Ceará, Brazil.

\begin{tabular}{|c|c|c|c|c|c|}
\hline Farms & Production system & $\begin{array}{c}\text { Number of } \\
\text { drinkers }\end{array}$ & Type of drinkers & $\begin{array}{c}\text { Cleanliness of } \\
\text { drinkers }\end{array}$ & Stocking density $\left(\mathrm{m}^{2}\right)$ \\
\hline Farm 01 & Semi-intensive & 2 & Automathic drinker & Dirty & - \\
\hline $\begin{array}{l}\text { Farm } 02 \\
\text { (Group 01) }\end{array}$ & Semi-intensive & 1 & Automathic drinker & Clean & 8.25 \\
\hline $\begin{array}{l}\text { Farm } 02 \\
\text { (Group 2) }\end{array}$ & Semi-intensive & 1 & Automathic drinker & Partially dirty & 8.25 \\
\hline Farm 03 & Semi-intensive & 1 & Automathic drinker & Dirty & 11.81 \\
\hline Farm 04 & Semi-intensive & 2 & $\begin{array}{c}{ }^{1} \text { Bucket/ } \\
{ }^{2} \text { Automathic } \\
\text { drinker }\end{array}$ & $\begin{array}{l}{ }^{1} \text { Dirty/ } \\
{ }^{2} \text { Clean }\end{array}$ & 3.33 \\
\hline Farm 05 & Semi-intensive & 2 & Bucket & Partially dirty & 6.76 \\
\hline Farm 06 & Extensive & 1 & Lake & Clean & 4.85 \\
\hline Farm 07 & Extensive & 3 & $\begin{array}{l}{ }^{1} \text { Bucket/ } \\
{ }^{2} \text { Lake }\end{array}$ & $\begin{array}{l}{ }^{1} \text { Dirty/ } \\
{ }^{2} \text { Clean }\end{array}$ & 5.82 \\
\hline Farm 08 & Extensive & 1 & Bucket & Dirty & 7.87 \\
\hline Farm 09 & Extensive & 1 & Lake & Clean & 3.2 \\
\hline Farm 10 & Extensive & 2 & $\begin{array}{l}{ }^{1} \text { Bucket/ } \\
{ }^{2} \text { Lake }\end{array}$ & $\begin{array}{l}{ }^{1} \text { Partially dirty/ } \\
{ }^{2} \text { Clean }\end{array}$ & 6.4 \\
\hline Farm 11 & Extensive & 3 & Bucket & Partially dirty & 5.56 \\
\hline Farm 12 & Extensive & 2 & ${ }^{1}$ Bucket $/{ }^{2}$ Bucket & $\begin{array}{c}{ }^{1} \text { Clean/ } \\
{ }^{2} \text { Partially dirty }\end{array}$ & 2.28 \\
\hline Farm 13 & Extensive & 1 & Lake & Clean & 2.12 \\
\hline Farm 14 & Extensive & 1 & Lake & Clean & - \\
\hline Farm 15 & Extensive & 6 & Bucket & Partially dirty & - \\
\hline
\end{tabular}

${ }^{1,2}$ Refers to the type of drinkers and cleanliness of drinkers on each line of the table, respectively. 
adequate facility promotes a better relationship between animals and stock people due to optimization of management and diseases control on daily work, as well as protection for animals (SILVA et al., 2010).

All animals had water availability and drinkers working properly. There was a significant difference for type of drinkers $(\mathrm{P}=0.001)$. On farms with water only in buckets (Table 5), it is possible that goat does suffered from thirsty during day time, especially on $\mathrm{E}$ farms, since animals were released in Caatinga for at least $10 \mathrm{~h}$ and during dry periods the access to water points supply is lower (ARAÚJO et al., 2010). Likewise, large amount of farms with dirty or partially dirty drinkers (Table 5), both on $\mathrm{S}$ and E farms, was alarming. However, the extended dry period that is affecting Ceará since 2010 (MONITOR DE SECAS, 2016) increased the difficulty to access good quality water, being one of the most relevant factors for the data reported.

Access to shadow was provided to animals on all farms, and access to shelter was observed only on three $\mathrm{S}$ farms. There was significant difference for access to shelter $(\mathrm{P}=0.036)$, with $\mathrm{S}$ farms presenting access to shelter more frequently than $\mathrm{E}$ farms. New Zealand Government (2018) cited access to shelter as an important indicator due to several reasons: protection against rain, heat and wind, isolation during kidding period or hiding goat kids, and reduction of health and welfare problems as thermal stress. In semiarid regions, full protection against wind can be difficult to achieve with adequate thermal conditions to goats due to the hot climate during almost all year (ARAÚJO, 2011). This could explain the absence of shelters on E farms (100\%) and on S farms (50\%). Suitable and cheaper shelters should be implemented on northeast farms.

As for facilities for goats, it was identified two types: goat houses and rustic facilities. Goat houses refer to a more sophisticated facility, with internal divisions and presence of feeders, drinkers, salt shakers, ripped or cemented floor, and roof; rustic facilities indicated a place where there is no internal divisions, may or may not have feeders, and is usually done with bare soil (ALENCAR et al., 2010). In total, only three S farms had goat houses and all the others S and E farms had rustic facilities. There was significant difference for type of facility $(\mathrm{P}=0.008)$ comparing $\mathrm{S}$ and $\mathrm{E}$ farms. This result is only descriptive because it is not possible to infer that the degree of welfare of meat goat does have been influenced by the type of facility. Future studies should assess the degree of welfare of meat goat does with a focus on the impact of different types of facilities on the level of welfare of these animals.
Cleanliness of facilities was proposed by authors with the intention to verify if it was feasible (Figure 1). S and E farms were classified, respectively, as dirty $(40 \%, 70 \%)$, partially dirty $(40 \%, 10 \%)$, and clean $(20 \%, 20 \%)$. This situation is probably linked with results regarding frequency of cleanliness. Dirty facilities on E farms were cleaned each fifteen days or more, showing an inadequate farm management. However, there were some controversial results. For instance, on E farms considered clean, facilities were cleaned four times a year (Farm 09) or every fifteen days (Farm 15). On one E farm considered partially dirty, frequency of cleaning occurred every three days (Farm 15), and on the $S$ farm partially dirty, it occurred every two months (Farm 02). Another factor that may influence these two parameters is the type of floor. Bare soil was the type of floor presented on two $\mathrm{S}$ farms and on all $\mathrm{E}$ farms. Cement with bare soil was prevalent on two $\mathrm{S}$ farms. In order to promote a more suitable environment for animals, aiming good health and comfort, the authors indicated that cleaning should be performed because wet and muddy grounds are predisposing factors for lameness (EFSA, 2014). Further studies of the influence of type of floor on the cleaning of facilities should be conducted.

At individual level, 344 meat goat does were evaluated, with 151 from S farms and 193 from $\mathrm{E}$ farms. In relation to the individual assessment, regarding BCS, results are provided with the number of goats followed by total percentage (\%) comparing $\mathrm{S}$ and $\mathrm{E}$ farms, respectively. Categories were very thin $(\mathrm{n}=28 ; 18.54 \%$ and $\mathrm{n}=28 ; 14.50 \%)$, thin $(\mathrm{n}=58 ; 38.41 \%$ and $\mathrm{n}=68 ; 35.23 \%)$, adequate $(\mathrm{n}=50 ; 33.11 \%$ and $\mathrm{n}=72 ; 37.30 \%)$, fat $(\mathrm{n}=9 ; 5.96 \%$ and $\mathrm{n}=21 ; 10.88 \%)$ and very fat $(n=6 ; 3.67 \%$ and $n=4 ; 2.07 \%)$. There was no significant difference between $\mathrm{S}$ and $\mathrm{E}$ farms related to $\mathrm{BCS}(\mathrm{P}=0.157)$. This result surprised the authors, as it was expected that goats that received supplemental food on $\mathrm{S}$ farms would present a more adequate score than animals on E farms that only had access to Caatinga pasture. Similar results in both production systems probably occurred because there were goats in $\mathrm{S}$ farms in different physiological stages, as lactation, gestation and growing, and the concentrated feeding provided for them was not adequate on a nutritional point of view to ensure a good body condition score for all goats (COSTA et al., 2008).

Animal-based parameters are depicted on Table 6. Occurrence of animals with soft feces on both $\mathrm{E}$ and $\mathrm{S}$ farms showed that this evaluation is more accurate when performed individually than in group (Table 4). Presence of animals with dry feces on both sides of tail indicated that goats had 


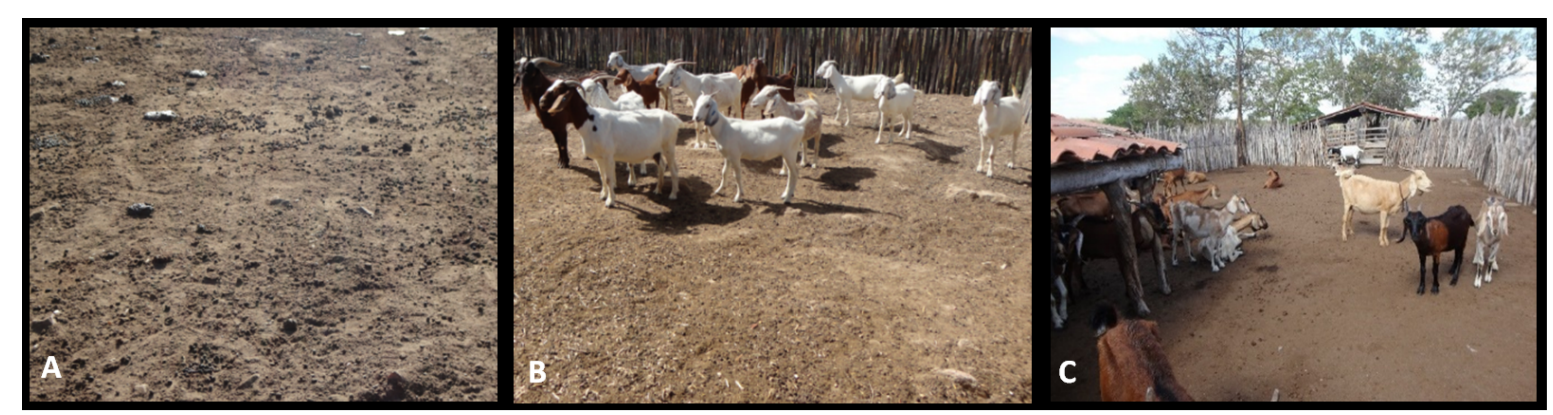

Figure 1 - Evaluation regarding the indicator cleanliness of facilities. A) Dirty facility. B) Partially dirty facility. C) Clean facility. Fonte: Luana Oliveira Leite.

diarrhea, possibly due to gastrointestinal helminthes, common and serious threats for small ruminants, that cause low productivity, morbidity and mortality on animals (SHARMA et al., 2020). Occurrence of abscess could be due to infectious diseases, as Caseous Lymphadenitis (SMITH \& SHERMAN, 2009) or improper management of vaccination being a probable cause of more animals with abscesses on $\mathrm{S}$ farms. In humans, formation of abscess was related to complications after intramuscular injections due to incorrect use of the technique at the time of application, use of small needles and introduction of pathogens by needles (CASSIANI \& RANGEL, 1999). This could be solved with adequate training of stockpeople.

Lower levels of ocular discharge was reported in dairy goats $(6 \%)$ on UK farms (ANZUINO et al., 2010) when compared to results of our study. In Brazilian Northeast, keratoconjunctivitis was also reported on farms in Ceará-BR (29.1\%) (PINHEIRO et al., 2000) and Paraíba-BR (38.2\%) (SANTOS et al., 2011). Excessively dusty supplementary feeds should not be provided for goats (NEW ZEALAND GOVERNMENT, 2018), which may be responsible for the higher incidence of ocular discharge on $\mathrm{S}$ farms during dry season. Occurrence of pneumonia in goats on farms in Ceará-BR (44.9\%) were related to rainy season (PINHEIRO et al., 2000). In the present study, only one goat on $\mathrm{S}$ farm presented persistent coughing probably due to the dust from the food; but monitoring and evaluation are required. Observation of vulvar discharge (Table 6) could berelated to pathologies associated with reproductive organs as caprine herpes virus (PUGH, 2002). As this indicator was not presented neither in the AWIN for goats (AWIN GOAT, 2015) or for sheep (AWIN SHEEP, 2015), further research regarding the vulvar discharge indicator should be carried out in order to observe the reliability and feasibility of this parameter.

Results of presence of minor and major

Table 6 - Prevalence of six animal-based indicators on goats individually assessed on five $\mathrm{S}$ farms $(\mathrm{n}=151)$ and on ten $\mathrm{E}$ farms $(\mathrm{n}=193)$.

\begin{tabular}{|c|c|c|c|c|c|}
\hline \multirow[t]{2}{*}{ Animal health Indicators } & \multicolumn{2}{|c|}{ Number (\%) } & \multicolumn{2}{|c|}{ Number (\%) } & \multirow[t]{2}{*}{ P-valor } \\
\hline & Goats & $\mathrm{S}$ farms & Goats & E farms & \\
\hline Faecal soiling & $5(3.31)$ & $3(60.0)$ & $6(3.10)$ & $4(40.0)$ & 1.000 \\
\hline Abscess & $25(16.55)$ & $4(80.0)$ & $19(9.84)$ & $7(70.0)$ & $0.044^{*}$ \\
\hline Nasal discharge & $11(7.28)$ & $2(40.0)$ & $8(4.14)$ & $6(60.0)$ & 0.206 \\
\hline Ocular discharge & $24(15.89)$ & $4(80.0)$ & $16(8.29)$ & $4(40.0)$ & $0.029^{*}$ \\
\hline Vulvar discharge & $0(0.0)$ & $0(0.0)$ & $2(1.03)$ & $2(20.0)$ & 0.506 \\
\hline Respiration quality & $1(0.66)$ & $1(20.0)$ & $0(0.0)$ & $0(0.0)$ & 1.000 \\
\hline
\end{tabular}

${ }^{*}$ Significant difference $(\mathrm{P}<0.05)$. 


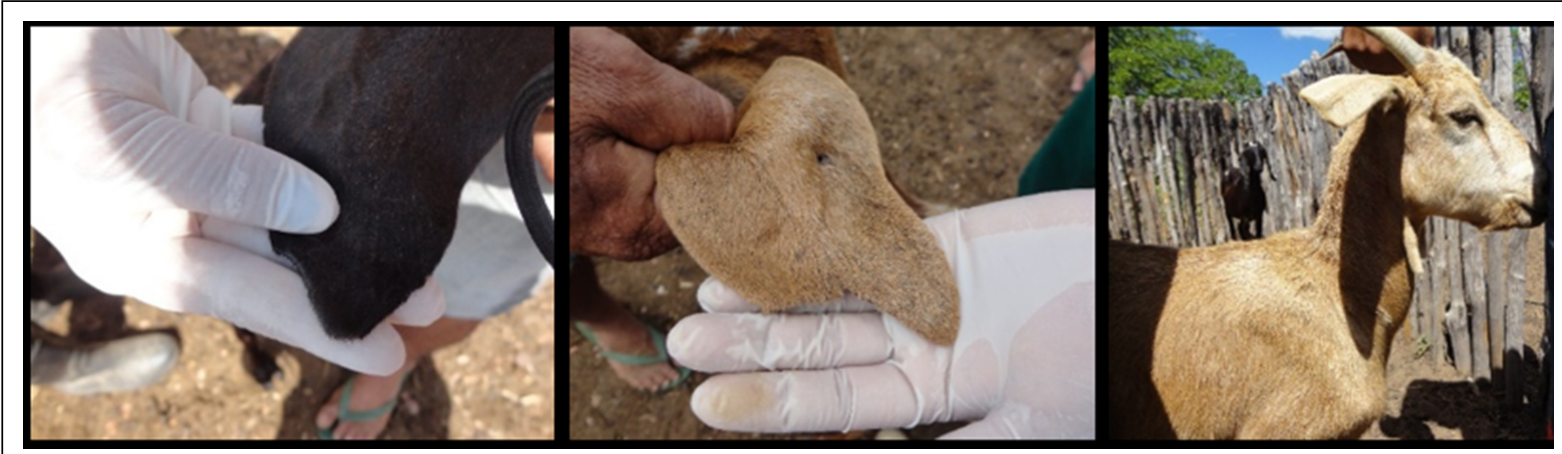

Figure 2 - Different ear cuts in meat goat does performed on E farms in Ceará, Brazil. Fonte: Fabiana de Orte Stamm.

lesion without myiasis related to each variable of Lesions (L) were provided with the number of goats followed by total percentage $(\%)$ on animals on $\mathrm{S}$ and E farms, respectively. Minor lesions were observed on ears $(n=16 ; 10.59 \%$ and $n=17 ; 8.80 \%)$, neck $(n=3$; $1.98 \%$ and $n=1 ; 0.51 \%)$ and body $(n=3 ; 1.98 \%$ and $\mathrm{n}=4 ; 2.07 \%)$. Minor lesions in eyes $(\mathrm{n}=1 ; 0.51 \%)$ and in face/muzzle $(n=3 ; 1.55 \%)$ were observed only on $\mathrm{E}$ farms. Major lesions was observed in ears $(\mathrm{n}=2 ; 1.32 \%$ and $\mathrm{n}=62 ; 32.12 \%)$, neck $(\mathrm{n}=2 ; 1.32 \%$ and $n=2 ; 1.03 \%)$ and body $(n=1 ; 1.06 \%$ and $n=1$; $0.51 \%)$. There was significant difference $(\mathrm{P}=0.001)$ in major lesions related to ears, being more frequent on goats from $\mathrm{E}$ farms (Figure 2). This practice is used in order to identify animals from a herd; however, compared to other techniques as tattoos and ear tags, it not allows individual identification; and consequently, the record of vaccination date, diseases and deliveries are not done (ALENCAR et al., 2010). This technique is usually performed with knives without anesthesia or pain relief after the procedure. It is a form of mutilation of the animal. According to New Zealand Government (2018), ears of goats are very sensitive and care should be provided during identification procedure to avoid damage on cartilage ridges and blood vessels. Although, application of ear cuts in goats was probably due to cultural heritage, education of farmers regarding animal sentience are fundamental to change this reality.

Lesions in head and body could be due to traumas, skin damage and hair losses (ANZUINO et al., 2010). Stock people from northeast reported barbed wire type of fence as an important cause of injuries in goats (BRITO et al., 2005). Barbed wire were presented on some of the evaluated farms, especially in E farms. There was no minor or major lesions in udder and teats of goats as well as there was no presence lesions with myiasis on $\mathrm{S}$ and $\mathrm{E}$ farms. However injuries in udder and teats were not reported in this study, alterations in teats and/or milk occurred on farms $(n=112 ; 76.7 \%)$ in PernambucoBR (ALENCAR et al., 2010), being important to be alert to this type of lesion.

During the application of this welfare protocol in meat goat does, the authors made suggestions regarding the use of some indicators:

1) Cleanliness of facilities may be a good indicator, but more studies need to be performed to confirm its validity and reliability;

2) Assessments in Ceará and in semiarid regions must be applied on both rainy and dry seasons due to differences on edaphoclimatic conditions observed in these two periods;

3) Leg injuries, especially in knees, may be used in the assessment of the welfare in meat goat does;

4) Queuing at feeding may be used in the assessment of the welfare in meat goat does when animals have part or all of their food intake in the trough. This was not the case for most of the animals evaluated on this study;

5) Studies related to the importance of each indicator should be carried out, aiming the classification of farms regarding quality of life of the animals, and facilitating the guidance of producers for the resolution of the most relevant findings.

\section{CONCLUSION}

Most indicators selected in this protocol were simple and practical to use on-farm, probably due to their applicability on dairy goats and sheep. The assessment time for each farm ranged from 1 to 3 hours. It is possible that time will increase on farms with a greater number of animals. Due to different values of ambient variables, it is recommended to

Ciência Rural, v.50, n.10, 2020. 
perform all evaluations during the afternoon. At group level, oblivion and thermal stress were the only indicators that differed between both groups, being, respectively, more frequently observed on goats from $\mathrm{S}$ and $\mathrm{E}$ farms. At individual level, the main findings were the high occurrence of abscess, ocular discharge and lesions. Similarities between results showed that farmers in both production systems faced problems due to heat stress, lack of forage, and health issues. However, producers from $\mathrm{S}$ farms seems to have a better financial situation and are able to provide a better living condition to the goats under their care.

In order to identify the main problems affecting the welfare degree of meat goat does, the authors recommend the application of this protocol on different farms in semiarid regions, being the first step towards raising goats more aware of the challenges faced on each farm. After the assessments, it is fundamental to pass the results to the producers and encourage their education aiming to promote a management of meat goat does that integrate animal welfare practices.

\section{ACKNOWLEDGEMENT}

This study was financed in part by the Coordenação de Aperfeiçoamento de Pessoal de Nível Superior - Brasil (CAPES) - Finance Code 001. We would also like to thank the producers and handlers who made themselves available to assist us during the research.

\section{BIOETHICS AND BIOSSECURITY COMMITTEE APPROVAL}

This study was approved by Ethics Committee of Federal University of Paraná, protocol number 029/2016.

\section{DECLARATION OF CONFLICT OF INTERESTS}

The authors declared no potential conflicts of interest with respect to the research, authorship, and/or publication of this article.

\section{AUTHORS' CONTRIBUTIONS}

LOL was responsible for the elaboration, execution and writing of the research. FOS worked assisting in the execution and in the research writing. MAC and JACF worked in the experimental design of the work and in the analysis of all data. RCMG acted coordinating, elaborating and assisting the research writing.

\section{REFERENCES}

ALENCAR, S. P. et al. Sanitary profile of the goat and sheep breeding of the hinterland of Pernambuco.Ciência Animal Brasileira, v.11, n.1, p.131-140, 2010. Available from: $<$ https:// www.revistas.ufg.br/vet/article/view/4051/6518>. Accessed: Dec. 16, 2016. doi: 10.5216/cab.v11i1.4051.

ALMEIDA, E.P.C.et al. Luvissolos crônicos. Agência Embrapa de Informação Tecnológica (AGEITEC). 2020. Available from: $<$ https://www.agencia.cnptia.embrapa.br/gestor/solos_tropicais/ arvore/CONT000gn230xhm02wx5ok0liq1 mqv181o $7 \mathrm{y} \cdot \mathrm{html}>$. Accessed: Jan. 29, 2020.

ANZUINO, K. et al. Papers assessment of welfare on 24 commercial UK dairy goat farms based on direct observations. Veterinary Record, v.167, p.774-780, 2010. Available from: <veterinaryrecord.bmj.com/content/167/20/774.long>. Accessed: Dec. 10, 2016. doi: 10.1136/vr.c5892.

ARAÚJO, G. G. L. DE et al. Water and small ruminant production. Revista Brasileira de Zootecnia, v.39, p.326-336, 2010. Available from: <scielo.br/pdf/rbz/v39sspe/36.pdf>. Accessed: Dec. 23, 2016. doi: $10.1590 / \mathrm{S} 1516-35982010001300036$

ARAÚJO, S. M. S. A região semiárida do nordeste do Brasil: questões ambientais e possibilidades de uso sustentável dos recursos. Rios Eletrônica, p.89-90, 2011. Available from: $<$ https://www.fasete.edu.br/revistarios/media/revistas/2011/5/a regiao_semiarida_do_nordeste_do_brasil.pdfhttp://www.scielo.br/ scielo.php?script $=$ sci_arttext\&pid $=$ S1516-35982010001300036>. Accessed: Jan. 06, 2017.

AWIN GOAT. Animal Welfare Indicators for Goats. 2015. Available from: <https://air.unimi.it/retrieve/ handle/2434/269102/384790/AWINProtocolGoats.pdf $>$. Accessed: Jan. 10, 2017.

AWIN PROJECT. Animal Welfare Indicators. 2015. Available from: $\quad<$ http://cordis.europa.eu/project/rcn/99394/reporting $>$. Accessed: Jan. 10, 2017.

AWIN SHEEP. Animal Welfare Indicators for Sheep.2015 Available from: <http://uni-sz.bg/truni11/wp-content/uploads/ biblioteka/file/TUNI10015667(1).pdf $>$. Accessed: Jan. 10, 2017.

BATTINI, M. et al. Invited review: animal-based indicators for onfarm welfare assessment for dairy goats. Journal of Dairy Science, v.97, p.1-24, 2014. Available from: <http://www.sciencedirect. com/science/article/pii/S00220302140064444>. Accessed: Jan. 13, 2017. doi: 10.3168/jds.2013-7493.

BATTINI, M. et al. Feasibility and validity of animal-based indicators for on-farm welfare assessment of thermal stress in dairy goats. International Journal of Biometeorology, v.60, p. 289-296, 2016. Available from: <https://link.springer.com/article/10.1007/ s00484-015-1025-7>. Accessed: Jun. 26, 2020.

BERG, W. et al. A scoring system for coat and tail condition in ringtailed lemurs, Lemur catta. American Journal of Primatology, v.71, n.3, p.183-190, 2009. Available from: <https://onlinelibrary. wiley.com/doi/abs/10.1002/ajp.20652>. Accessed: Jan. 13, 2017. doi: 10.1002/ajp.20652

BLOKHUIS, H. J. et al. The welfare quality ${ }^{\circledR}$ project and beyond: Safeguarding farm animal well-being. Acta Agriculturae Scandinavica, Section A - Animal Science, n.60, p.129-140, 2010. Available from: <www.tandfonline.com/doi/abs/10.1080/09 064702.2010.523480>.Accessed: Nov. 30, 2016. doi: https://doi.or $\mathrm{g} / 10.1080 / 09064702.2010 .523480$. 
BRITO, D. R. B.et al.Ectoparasites in goat and sheep folks from Alto Mearim and Grajaú Microregion, state of Maranhão. Revista Brasileira de Parasitologia Veterinária, v.14, n.2, p.59-63, 2005. Available from: <http://www.redalyc.org/articulo. oa?id=397841454005 > . Accessed: Jan. 18, 2017.

CAROPRESE, M. et al. Monitoring the on-farm welfare of sheep and goats. Italian Journal of Animal Science, v.8, n.1, p.343, 2009. Available from: $<$ https://www.researchgate.net/ publication/41393417 Monitoring the on-farm welfare of sheep_and_goats $>$. Accessed: Jan. 20, 2017. doi: 10.4081/ ijas.2009.s1.343.

CASSIANI, S. H. B.; RANGEL, S. M. Site adverse reactions after intramuscular injections in adults: review of literature. Usp-Rp, v.32, n.2, p.444-450, 1999. Available from: <http://www.revistas. usp.br/rmrp/article/view/12716/14497>. Accessed: Jan. 21, 2017.

CHRISTODOULOPOULOSG. Foot lameness in dairy goats. Research in Veterinary Science, v.86, p.281-284, 2009. Available from: $\quad<\mathrm{https}: / /$ www.sciencedirect.com/science/article/abs/pii/ S0034528808001628>. Accessed: Jan. 29, 2020.

CODEVASF. Manual de Criação de Caprinos e Ovinos. 2011. Available from: <https://www.codevasf.gov.br/acesso-ainformacao/institucional/biblioteca-geraldo-rocha/publicacoes/ arquivos/Manual_Ovinos_e_Caprinos_Verso_Final_rev_jun2011. pdf $>$. Accessed: Jan. 10, 2017.

COSTA, R. G. et al. Characterization of the goat and sheep production system in the semi-arid region of the state of Paraíba, Brazil.Archivos de Zootecnia, v.57, n.218, p.195-205, 2008 . Available from: $<$ https://ainfo.cnptia.embrapa.br/digital/bitstream/ item/28853/1/API-Caracterizacao-sistema-de-producao-caprinoe-ovino.pdf $>$. Accessed: Jan. 25, 2017.

EFSA. Scientific Opinion on the welfare risks related to thefarming of sheep for wool, meat and milk production. EFSA Journal, v.12, n.12, p.1-128, 2014. Available from: <https://efsa.onlinelibrary.wiley.com/ doi/pdf/10.2903/j.efsa.2014.3933>. Accessed: Aug. 25, 2019.

EZE, C.A. Lameness and reproductive performance in small ruminants in Nsukka Area of the Enugu State, Nigeria. Small Ruminant Research, v.44, p.263-267, 2002. Available from: $<$ https://www.sciencedirect.com/science/article/abs/pii/ S0921448802000305>. Accessed: Jan, 29, 2020.

FAO and INPhO. Farm Structures in tropical climates. Animal environmental requirements. 1998. Available from: $<$ http://www. fao.org/3/s1250e/S1250E $10 . h$ tm\#Animal\%20environmental\%20 requirements>. Accessed: Feb. 20, 2017.

IBGE. Produção pecuária municipal. 2016. Available from: $<$ https://biblioteca.ibge.gov.br/visualizacao/periodicos/84/ ppm_2016_v44_br.pdf>. Accessed: Jan. 9, 2017.

IPECE. Região semi-árida cearense. 2005. Available from: $<$ http://www2.ipece.ce.gov.br/atlas/capitulo1/12/pdf/Regiao Semi_Arida.pdf $>$. Accessed: Dec. 14, 2016.

LEITE, L. O. et al.Indicators to assess goat welfare on-farm in the semiarid region of Brazilian Northeast. Ciência Rural, v.47, p.18, 2017. Available from: $<$ http://www.scielo.br/pdf/cr/v47n9/16784596-cr-47-09-e20161073.pdf $>$. Accessed: Nov. 10, 2017. doi: $10.1590 / 0103-8478 \mathrm{cr} 20161073$.
LICKLITER, R. E. Behavior associated with parturition in the domesti goat. Applied Animal Behaviour Science, v.13, p.335345, 1985. Available from: <https://www.sciencedirect.com/ science/article/abs/pii/0168159185900139>. Accessed: Feb. 01, 2017. doi: 10.1016/0168-1591(85)90013-9.

LOIOLA, M. I. B. et al. Caatinga: vegetação do semiárido brasileiro. Ecologi@, v.4, p.14-19, 2012. Available from: <https:// speco.pt/images/Artigos_Revista_Ecologia/revistaecologia_4. pdf\#page $=15>$. Accessed: Jan. 29, 2020.

McMANUS, C. Distribution of goat breeds in Brazil and their relationship with environmental controls. Bioscience Journal, v.30, n.6, p.1819-1836, 2014.

MIRANDA-DE LA LAMA, G. C.; MATTIELlO, S. The importance of social behaviour for goat welfare in livestock farming. Small Ruminant Research, v.90, p.1-10, 2010. Available from: $\quad<\mathrm{https}: / /$ www.sciencedirect.com/science/article/abs/pii/ S0921448810000192>. Accessed: Jan. 29, 2020.

MONITOR DE SECAS.Monitor das secas do Nordeste brasileiro. 2016. Available from: <monitordesecas.ana.gov.br>. Accessed: Feb. 23, 2017.

NEW ZEALAND GOVERNMENT. Animal Welfare (Goats) Code of Welfare. 2018. Available from: <https://www.mpi.govt. nz/dmsdocument/1429/direct f $>$. Accessed: Jan. 19, 2019.

PINHEIRO, R. R. et al. Epidemiological aspects of the raising goat in Ceará State, Brazil.Arquivo Brasileiro de Medicina Veterinaria e Zootecnia, v.52, n.5, p.534-543, 2000. Available from: <http:// www.scielo.br/scielo.php? script=sci_arttext\&pid $=\mathrm{S} 0102$ $09352000000500021 \& \operatorname{lng}=$ en\&nrm $=$ iso\&tlng $=\mathrm{pt}>$. Accessed: Feb. 01, 2017. doi: 10.1590/S0102-09352000000500021.

PUGH, D. G. Sheep \& Goat Medicine. Philadelphia: Saunders, 2002. $468 \mathrm{p}$

SANTOS, T. C. P. et al.Sanitary management aspects of goat and ovine farm in the micro-region of Patos in semi-arid area of Paraíba state.Ciência Animal Brasileira, v.12, n.2, p.206-212, 2011. Available from: <https://www.revistas.ufg.br/vet/article/ view/4420/9214>. Accessed: Mar. 10, 2017. doi: 10.5216/cab. v12i2.4420.

SEBRAE. Manejo Básico de Ovinos e Caprinos. 2009 Available from: $<$ https://www.caprilvirtual.com.br/Artigos/ ManejoBasicoOvinoCaprinoSebrae.pdf $>$. Accessed: Jan. 10, 2017.

SHARMA, D.K. et al. Gastrointestinal Helminthic Challenges in Sheep and Goats in Afro-Asian Region: A Review. Journal of Animal Research, v.10, n.1, p.1-18, 2020. Available from: $<$ https://ndpublisher.in/admin/issues/JARv10n1a.pdf $>$. Accessed: Jun. 26, 2020.

SILANIKOVE, N. Effects of heat stress on the welfare of extensively manageddomestic ruminants.Livestock Production Science, v.67, p.1-18, 2000. Available from: <https://www. sciencedirect.com/science/article/abs/pii/S0301622600001627>. Accessed: Jun. 26, 2020.

SILVA, F. L. R. DA; ARAÚJO, A. M. DE. Performance of crossbred goats in the semi-arid northeast of Brazil.Revista Brasileira de Zootecnia, v.29, n.4, p.1028-1035, 2000. Available from: <http:// www.scielo.br/pdf/rbz/v29n4/5615.pdf > . Accessed: Mar. 20, 2017. 
SILVA, V. R. DA et al. Instalattions for goats. Revista Educação Agrícola Superior, v.25, n.2, p.99-103, 2010. Available from: $<$ https://docplayer.com.br/26077908-Revista-educacao-agricolasuperior-associacao-brasileira-de-educacao-agricola-superiorabeas-v-25-n-2-p-instalacoes-para-caprinos.html>. Accessed: Jun. $15,2017$.

SMITH, M. C.; SHERMAN, D. M. Goat Medicine.2 ed. Ames: Wiley-Blackwell, 2009. 871p.
WAIBLINGER, S. et al. Assessing the human-animal relationship in farmed species: A critical review. Applied Animal Behaviour Science, v.101, p.185-242, 2006. Available from: $<$ https://www. sciencedirect.com/science/article/pii/S0168159106000475>. Accessed: Feb. 01, 2017. doi: 10.1016/j.applanim.2006.02.001.

WELFARE QUALITY ${ }^{\circledR}$. 2009.Welfare Quality Network. Available from: $<$ http://www.welfarequality.net/en-us/home/ $>$. Accessed: Dec. 10, 2016. 